\title{
A New Approach to the Concepts of Conservation to Identify and Evaluate Railway Heritage through Indicators ${ }^{1}$
}

\author{
Breno Albuquerque B. Borges \\ Centro Interuniversitário de História das Ciências e da Tecnologia (CIUHCT) \\ Faculdade de Ciências e Tecnologia, Universidade NOVA de Lisboa \\ ba.borges@campus.fct.unl.pt
}

\begin{abstract}
The wide railway universe, with its particular and peculiar characteristics, requires the implementation of criteria to improve the identification and conservation of cultural goods. Recently concepts of authenticity, integrity and cultural significance have been identified as fundamental in the selection of the cultural heritage of humanity. Although we find these concepts being analyzed in theory as independents, through a theoretical-methodological reflection, this $\mathrm{PhD}$ research argues that, in practice, they are interconnected, and therefore should be approached together. Following the contemporary theory of conservation, my doctoral research aims at contributing to the conservation of railways' heritage using this new approach, by proposing new indicators as assessment tools so that conservation institutions will be able to identify railway goods as cultural heritage. The research uses the Railway Complex of Barreiro, in Portugal, as a case study.
\end{abstract}

Keywords: Railways heritage; heritage conservation; theory of conservation; concepts of heritage; institutions

\footnotetext{
${ }^{1}$ This Work in Progress is based on my ongoing PhD research in History, Philosophy and Heritage of Science and Technology, supervised by Professors Maria Paula Diogo and Paula Urze, at the Faculty of Sciences and Technology, NOVA University of Lisbon, Portugal, and the Virgínia Pontual, at Center of Arts and Communication of the Federal University of Pernambuco, Brazil.
} 


\title{
Railways as Industrial and Cultural Heritage
}

Railway heritage is associated with industrial heritage, its richness lying in its formal diversity, use and scale. It includes not only tangible goods (movable and immovable), but also intangible goods (knowledge and mores). Railroads created an universe of their own, since they produced specific buildings such as train stations, warehouses, housing units for employees, locomotive workshops, as well as engineering works such as tunnels, bridges, viaducts, roundabouts, and many others, which are, according to Eric Hobsbawm, symbols of technological achievements:

\begin{abstract}
The iron road, pushing its huge smoke-plumed snakes at the speed of wind across countries and continents, whose embankments and cuttings, bridges and stations, formed a body of public building beside which the pyramids and the Roman aqueducts and even the Great Wall of China paled into provincialism, was the very symbol of man's triumph through technology. ${ }^{2}$
\end{abstract}

The interest in industrial legacy dates back to the late-eighteenth century in France and nineteenth century in countries like Portugal, Sweden and the United Kingdom. ${ }^{3}$ It was, however, in England, in the 1950s, that a more substantial interest arose and the term "industrial archeology" ${ }^{4}$ began to be used..$^{5}$ In 1962, the debate became more prominent when major railway traces, such as the Euston Station in London and the Coal Exchange, were demolished. However, even if it was a reference for technical and technological development, industrial heritage took a long time to be perceived as cultural heritage. In 1973, the 1st International Conference for the Conservation of Industrial Heritage was held at the then recently open museum in Ironbridge Gorge (Great Britain), hosting numerous authors from different countries, who had pioneered industrial preservation.

Official recognition of industrial preservation occurred only in 1978, during the 3rd International Congress for Conservation of Industrial Monuments held in Stockholm, with the creation of the TICCIH - The International Committee for the Conservation of the Industrial Heritage, which aimed at promoting a debate on the preservation of industrial heritage and international cooperation.

In Portugal, the Industrial Archeology Association of the Lisbon Region (AAIRL) was created

\footnotetext{
${ }^{2}$ Eric Hobsbawm, The Age of Revolution: 1789-1848 (London: Weidenfeld \& Nicolson, 1962), 44.

${ }_{3}^{3}$ Beatriz M. Kühl, Preservação do Patrimônio Arquitetônico da Industrialização: Problemas Teóricos de Restauro (São Paulo: Ateliê editorial, 2008), 37.

${ }^{4}$ Marilyn Palmer and Peter Neaverson, Industrial Archaeology: principles and practice (London: Taylor \& Francis e-Library, 2001).

${ }^{5}$ Specific bibliography points to Donald Dudley, a professor at the University of Birmingham, as the first to use the term in lectures. The first publication to use these words was written by Michael Rix, in the essay "The Amateur Historian," which affirms the importance of industrial documents and the preservation of buildings at risk of demolition. See Kenneth Hudson, Industrial Archaeology: An Introduction (London: Routledge, 2015), 21.
} 
in 1980 to encourage the studies in the field of industrial archeology and to safeguard its heritage. In 1986, it was followed by the Portuguese Association of Industrial Archeology (APAI), which nowadays continues to pursue its goals of studying, protecting, conserving and valuing the material and immaterial traces of the industrial society. ${ }^{6}$

It was only in 2003 that the discussion on the definition of industrial heritage was finally settled, with the approval of the Nizhny Tagil Charter, ${ }^{7}$ in Russia, during the XII International Congress held by TICCIH. It was thus defined as follows:

(...) [industrial heritage] consists of the remains of industrial culture which are of historical, technological, social, architectural or scientific value. These remains consist of buildings and machinery, workshops, mills and factories, mines and sites for processing and refining, warehouses and stores, places where energy is generated, transmitted and used, transport and all its infrastructure, as well as places used for social activities related to industry such as housing, religious worship or education. ${ }^{8}$

And industrial archaeology was described as:

(...) an interdisciplinary method of studying all the evidence, material and immaterial, of documents, artefacts, stratigraphy and structures, human settlements and natural and urban landscapes, created for or by industrial processes. It makes use of those methods of investigation that are most suitable to increase understanding of the industrial past and present.

(...) In addition, it draws on the study of work and working techniques encompassed by the history of technology. ${ }^{9}$

The Charter became a background document in the area, contributing to the definition of industrial heritage and showing its nature and dimension. Despite mentioning that industrial archeology uses "the most appropriate methods to increase the understanding of the industrial past and present," it did not add details about methodological issues.

A second important document is the Dublin Principle, published in 2011, which expands the concept of preservation of industrial heritage into an intangible dimension, thus taking into account technical know-how, the organization of work and workers, as well as the social

\footnotetext{
${ }^{6}$ Jorge Custódio and Deolinda Folgado, "A arqueologia e património arqueológico-industrial, no âmbito da Arqueologia Portuguesa," in Encontros Cem Anos de Arqueologia, "O Archeólogo Portugue区s" - Actas, eds. Maria Isabel Silva, Maria Isaura dos Santos Maia, Maria José Carvalho e Sousa and Paulo Costa Pinto, 209-25 (Vila do Conde: Associação de Protecção ao Património Arqueológico de Vila do Conde, 1998).

7 TICCIH, "The Nizhny Tagil Charter for the Industrial Heritage" (2003), accessed March 2, 2020, https:/ticcih.org/wp-content/uploads/2013/04/NTagilCharter.pdf, 3.

${ }^{8}$ Ibid., 2.

${ }^{9}$ Ibid.
} 
and cultural life of industrial communities. ${ }^{10}$ In addition, it points out the need for a more contextualized analysis of industrial heritage.

The industrial heritage consists of sites, structures, complexes, areas and landscapes as well as the related machinery, objects or documents that provide evidence of past or ongoing industrial processes of production, the extraction of raw materials, their transformation into goods, and the related energy and transport infrastructures. Industrial heritage reflects the profound connection between the cultural and natural environment, as industrial processes - whether ancient or modern - depend on natural sources of raw materials, energy and transportation networks to produce and distribute products to broader markets. It includes both material assets - immovable and movable -, and intangible dimensions such as technical know-how, the organization of work and workers, and the complex social and cultural legacy that shaped the life of communities and brought major organizational changes to entire societies and the world in general. ${ }^{11}$

Based on the international documents framing the understanding of industrial and railway heritage, my research project uses the concept of railway heritage as cultural heritage, associated with railway history, thus including: engineering and building structures and their socio-spatial relations; technology and work techniques; infrastructures; machinery and tools; the knowhow of the railway techniques and the landscapes. All of these elements were analyzed in an integrated and contextualized way.

Throughout the conceptual discussions, it is almost unanimous among specialists that industrial heritage must be based on theoretical and methodological references from various fields of knowledge, such as history, archeology, sociology, architecture, restoration, amongst others, not being characterized as an autonomous discipline. Françoise Choay ${ }^{12}$ states that industrial heritage has particular characteristics in relation to cultural heritage, namely its nature and scale, as well as its identification and identity. According to Anthony Coulls et al., ${ }^{13}$ these specific characteristics of industrial sites mean that the criteria for designating them as "World Heritage" cannot be the same for other types of heritage, which means that specific criteria must be developed and improved. Furthermore, there is still a lack of literature concerning instruments for the identification of industrial heritage. Actually, there are ongoing discussions

${ }^{10}$ Ana Paula Bitencourt, "O patrimônio industrial ferroviário e os instrumentos voltados para a sua salvaguarda," Architecton - Revista de Arquitetura e Urbanismo 2, no. 3 (2012): 17-25, on 21.

${ }^{11}$ ICOMOS, "Dublin Principles, Joint ICOMOS - TICCIH Principles for the Conservation of Industrial Heritage Sites, Structures, Areas and Landscapes" (2011), accessed March 2, 2020, https:// ticcih.org/wp-content/uploads/2013/10/GA2011_ICOMOS_TICCIH_joint_principles_EN_FR_ final_20120110.pdf, articles 1, 2, 3 .

${ }^{12}$ Françoise Choay, A alegoria do património (Lisboa: Ediçôes 70, 2014), 234.

${ }^{13}$ Anthony Coulls, Colin Divall and Robert Lee, "Railways as world heritage sites" Occasional Papers for the World Heritage Convention (ICOMOS, 1999), accessed April 12, 2020, https://www.icomos.org/ studies/railways.pdf, 5. 
on methods and criteria so as to generate guidelines for the selection of the assets to be safeguarded; however, specific norms and rules are still to be systematized and implemented.

\section{Brief Explanation About Concepts of Conservation}

As an international reference, the United Nations Educational, Scientific and Cultural Organization (UNESCO) uses the concepts of authenticity and integrity also as cultural significance, for the inscription of cultural goods on the World Heritage List. As an international parameter, it guides the conservation of cultural goods worldwide, at national and municipal levels.

The term authenticity, focused on cultural heritage, first appeared in the Venice Charter (1964), ${ }^{14}$ right in the first paragraph:

Imbued with a message from the past, the historic monuments of generations of people remain to the present day as living witnesses of their age-old traditions. People are becoming more and more conscious of the unity of human values and regard ancient monuments as a common heritage. The common responsibility to safeguard them for future generations is recognized. It is our duty to hand them on in the full richness of their authenticity. ${ }^{15}$

In the mid-1960s, the concept of authenticity was shaped by the Western perspective, closely associated with materiality. Nonetheless, with the Nara Charter, in 1994, ${ }^{16}$ this understanding changed. That is to say it was expanded to immaterial issues, such as know-how. The main contribution of the latter was to consider the cultural context of each heritage.

Since then, authenticity has been studied as a heritage's inherent and essential characteristic, which needs to be preserved. UNESCO currently defines authenticity as the continuity of cultural heritage attributes related to form and design, materials and substance, use and function, traditions and techniques, location and space, spirit and feeling, as well as other internal and external factors ${ }^{17}$; however, there is still a consensus that its understanding is not clear enough, as well as its operationalization.

${ }_{14}$ The Venice Charter is an international document that was on one of the resolutions of the Second International Congress of Architects and Technicians of Historic Monuments, held between 25 and 31 May 1964. Another resolution of this Congress, put forward by UNESCO, provided for the creation of the International Council on Monuments and Sites (ICOMOS). "International Charter for the Conservation and Restoration of Monuments and Sites (The Venice Charter 1964)," accessed February 5, 2020, https://www.icomos.org/charters/venice_e.pdf.

15 Ibid., 1.

${ }^{16}$ ICOMOS, “The Nara Document on Authenticity," (1994), accessed February 5, 2020 https://www. icomos.org/charters/nara-e.pdf

17 UNESCO, Operational Guidelines for the Implementation of the World Heritage Convention (Paris, 2019), 27. 
Recent scholarly work by authors such as Jukka Jokilehto, Herb Stovel, Lúcia Hidaka, Flaviana Lira, Paula Silva and Salvador Muñoz Viñas seek to better understand the notion of authenticity concerning cultural heritage, concluding that authenticity consists of its attributes' ability to transmit cultural values in a true or false way. ${ }^{18}$

On the other hand, the concept of integrity appeared in the international context of heritage conservation $^{19}$ as an idea of wholeness and intactness as referred in the article 8 of the Venice Charter, on the importance of maintaining elements of sculpture, painting or decoration as integral parts of a monument. In the last quarter of the twentieth century, the concepts of authenticity and integrity played a fundamental role in the selection of the cultural heritage of humanity when UNESCO published the first Operational Guidelines for the Implementation of the World Heritage Convention.

In the late 1960s, integrity was adopted as one of the evaluation criteria by UNESCO for the inclusion of natural goods in the List of Natural and Cultural Heritage, but in 2005, it was also adopted for the material heritage in the Operational Guide to World Heritage, which established the following definition:

Integrity is a measure of the wholeness and intactness of the natural and/or cultural heritage and its attributes. Examining the condition of integrity, therefore requires assessing the extent to which the property: a) includes all elements necessary to express its Outstanding Universal Value; b) is of adequate size to ensure the complete representation of the features and processes which convey the property's significance; c) suffers from adverse effects of development and/or neglect. ${ }^{20}$

Bernard Feilden and Jukka Jokilehto call the attention to the fact that integrity can also include a temporal dimension under the definition of historical integrity:

\footnotetext{
${ }^{18}$ Jukka Jokilehto, "Considerations on authenticity and integrity in world heritage context," City \& Time 2, no. 1 (2006): 1-16, accessed February 8, 2020, http://www.ceci-br.org/novo/revista/docs2006/ CT-2006-44.pdf; Herb Stovel, "Effective use of authenticity and integrity as world heritage qualifying conditions," City \& Time 2, no. 3 (2007): 21-36, accessed February 9, 2020, http://www.ceci-br.org/ novo/revista/docs2007/CT-2007-71.pdf; Lúcia T. F. Hidaka, "Indicador de avaliaçáo do estado de conservação sustentável de cidades-patrimônio cultural da humanidade: teoria, metodologia e aplicação" (PhD diss., Universidade Federal de Pernambuco, 2011); Flaviana B. Lira, Patrimônio cultural e autenticidade: montagem de um sistema de indicadores para o monitoramento (Recife: Ed. Universitária da UFPE, 2010); Flaviana B. Lira, "Da natureza complexa dos bens culturais: a indissociabilidade entre significância cultural, integridade e autenticidade," in Anais do V Encontro Internacional sobre patrimônio edificado - Arquimemória (Salvador: Departamento da Bahia do Instituto do Arquitetos do Brasil, 2017); Paula Maciel Silva, "Conservar, uma questão de decisão: o julgamento na conservação da arquitetura moderna” (PhD diss., Universidade Federal de Pernambuco, 2012); Salvador Muñoz Viñas, Contemporary Theory of Conservation (Oxford: Elsevier, 2005).

19 For further information read Rosane P. Loretto, "As [des]venturas da integridade no Patrimônio Mundial" (PhD diss., Universidade de São Paulo, 2016).

${ }^{20}$ UNESCO, Operational Guidelines, 27.
} 


\begin{abstract}
Over time, the original heritage resource may be partly damaged, intentionally modified or even destroyed, causing its potential unity to be diminished or lost. On the other hand, a historic resource may, at different periods of its history, become part of a new whole, through which it is redefined as part of a new potential unity; such transformations are part of its historical stratigraphy. Treatments aimed at the restoration of a heritage resource should refer to this new potential unity and should therefore be carried out within the framework defined by it. ${ }^{21}$
\end{abstract}

Therefore, in this perspective, a cultural object may undergo some changes and still keep its integrity. In line with the notion of authenticity of heritage, Lira ${ }^{22}$ states that integrity is directly related to the ability of a cultural good's attributes to transmit its significance. In fact, it is not about integrity when the good is conceived, but about its transformation in history. It is related to the permanent maintenance over time of the physical and dynamic elements which are necessary to tell the good's story.

Australia ICOMOS Burra Charter ${ }^{23}$ plays an important role in the paradigm shifted by defining conservation as "all the processes of looking after a place so as to retain its cultural significance," and cultural significance meaning:

aesthetic, historic, scientific, social or spiritual value for past, present and future generations (...) is embodied in the place itself, its fabric, setting, use, associations, meanings, records, related places and related objects. Places may have a range of values for different individuals or groups. ${ }^{24}$

In this framework, cultural significance refers to the quality of historical monuments, inherent or acquired over time, based on the relationship of these objects in their social context. The coexistence of these values, even in situations of divergence, is part of the construction of cultural meaning. ${ }^{25}$ Cultural significance is then composed of all the values ${ }^{26}$ attributed to the object in an diachronic arch, that is, present values are built upon data from the past and have

${ }^{21}$ Bernard M. Feilden and Jukka Jokilehto, Management Guidelines for world cultural heritage sites, 2nd ed. (Rome: ICCROM, 1998), 15.

${ }^{22}$ Lira, "Da natureza complexa dos bens culturais," 22.

23 The Burra Charter was first adopted in 1979 at the historic South Australian mining town of Burra. Minor revisions were made in 1981 and 1988, with more substantial changes in 1999. The Burra Charter: The Australia ICOMOS Charter for Places of Cultural Significance, (2013), accessed April 18, 2020, https://australia.icomos.org/wp-content/uploads/The-Burra-Charter-2013-Adopted-31.10.2013.pdf. ${ }^{24}$ Ibid., 2.

${ }^{25}$ Hidaka, "Indicador de avaliação," 120.

${ }^{26}$ On value see Aloïs Riegl, O culto moderno dos monumentos: a sua essência e a sua origem (São Paulo: Perspectiva, [1903], 2014); Marta de la Torre, ed., Assessing the Values of Cultural Heritage: Research Report (Los Angeles: The Getty Conservation Institute, 2002); Johannes Hessen, Filosofia dos valores (Coimbra: Almedina, 2001). 
the capacity to change the future. ${ }^{27}$

Cultural significance is the transmission of the object's meaning, whether with positive meanings, reminiscent of facts to be celebrated, or certain objects with negative meanings, such as Lira $^{28}$ exemplifies with the Berlin Wall, which is considered by many to be traumatic, uncomfortable, but a necessary historic fact to recall.

This new understanding of the concepts of integrity and authenticity was only possible due to the maturation of the understanding of heritage and monument. Apropos, Choay ${ }^{29}$ states it is shorthand to use these words as synonyms. In fact, in the thesis under development this will be clarified. The first to approach this issue was the Austrian art historian, Aloïs Riegl, author of "Der moderne Denkmalkultus: sein Wesen und seine Entstehung (1903). ${ }^{30}$ The word "monument" derives from the Latin noun monumentum, which is a derivative of the verb monere, meaning "to remember." It is, thus, appropriate to apply the term to any artifact, individual or collective, private or public, intentional or not, reminding people's memory, events, beliefs, rites or social rules which are part of their identity. ${ }^{31}$

Monuments have a specific function and their material presence act as a symbolic language in the cultural construction of human societies. They are intentionally built to "make history," by being a symbol for future generations. However, there is also the conception of an historical monument, which will become important due to the testimony of historical, economic, political, technical and even artistic events adding value to the place. The concept of historical monument is defined in the first article of the Venice Charter (1964), in the following way:

embraces not only the single architectural work but also the urban or rural setting in which is found the evidence of a particular civilization, a significant development or a historic event. This applies not only to great works of art but also to more modest works of the past which have acquired cultural significance with the passing of time. ${ }^{32}$

As the notion of a monument was expanded, so were the efforts to better understand conservation

${ }^{27}$ S. Zancheti, L. Hidaka, C. Ribeiro, and B. Aguiar, "A construção da significância cultural nos processos de conservação urbana" (unpublished manuscript, Recife, 2008), 7, quoted in Cecília Ribeiro and Flaviana Lira, "Autenticidade, Integridade e Significância Cultural," in Plano de Gestão da Conservação Urbana: Conceitos e Métodos, eds. Norma Lacerda and Sílvio Mendes Zancheti, 32-43 (Olinda: CECI, 2012), 39.

${ }^{28}$ Lira, "Da natureza complexa dos bens culturais," 11.

${ }^{29}$ Françoise Choay, As questôes do património: Antologia para um combate (Lisboa: Ediçôes 70, 2011), 15.

${ }^{30}$ In English Modern Cult of Monuments: its Character and its Origin. For this work in progress, I have read the Portuguese version, Riegl, $O$ culto moderno dos monumentos.

${ }^{31}$ Choay, As questóes do património, 16.

32 "International Charter for the Conservation and Restoration of Monuments and Sites (The Venice Charter, 1964)," article 1, 1. 
theories. To these efforts contributed theorists, such as: John Ruskin, who defended the value of patina, the signs of time and interventions only to extend a monument's lifetime; Eugène Violet-le-Duc, who strongly supported restoration and the aesthetic and stylistic value; and Camillo Boito, who stressed the value of monuments as documents, by registering the signs of time, and a scientifically based intervention. Cesare Brandi, in his book Theory of Restoration, in addition to highlighting the aesthetic and historical aspect of the work, points out that there is a subject-object relationship. ${ }^{33}$

This relationship shapes the meaning of looking at a monument from both as something from the past and something for the future, for the next generations. Muñoz Viñas ${ }^{34}$ considers that the traditional approach to cultural heritage, in which the aesthetic and historical (material) importance of the object was preserved, has been replaced in recent years by the subject-object relationship (immaterial), which supports the symbolic value, the use value, and meanings that are inherent to the matter; for Hidaka ${ }^{35}$, the meanings are just materialized in the attribute ${ }^{36}$ of heritage.

\section{Indicators as a Tool}

According to Zancheti and Hidaka, ${ }^{37}$ an indicator or several can simplify the complex and even the abstract phenomena in quantifiable measures used for monitoring, evaluation and decision making. According to Paulo Jannuzzi, ${ }^{38}$ indicators are instruments that transform abstract and non-measurable concepts into operational terms, allowing them to be expressed quantitatively. Therefore, the concepts proposed in my research can be subject to a quantitative approach by using a set of indicators.

For almost half a century, indicators have been used as a tool to analyze the performance of

\footnotetext{
${ }^{33}$ John Ruskin, The seven lamps of Architecture (New York: Dover Publications, 1989); Eugène E. Viollet-le-Duc, Restauração (São Paulo: Ateliê Editorial, 2000); Camillo Boito, Os restauradores (São Paulo: Ateliê Editorial, 2002); Cesare Brandi, Teoria da Restauração (São Paulo: Ateliê Editorial, 2004).

${ }^{34}$ Muñoz Viñas, Contemporary, 175-76.

${ }^{35}$ Hidaka, "Indicador de avaliação," 88.

${ }^{36}$ For Silvio Zancheti and Lúcia Hidaka attributes are any and all characteristics of the object and process that a person can identify as a heritage value, both material and nonmaterial. Silvio Zancheti and Lúcia Hidaka, Indicadores de Conservação e Sustentabilidade da Cidade Patrimonial (Olinda: CECI, 2011), 37.

${ }^{37}$ Ibid., 8.

${ }^{38}$ Paulo de Martino Jannuzzi, Indicadores Sociais no Brasil: Conceitos, Fontes de Dados e Aplicaçóes (Campinas: Editora Alínea, 2006), 15.
} 
the environmental, social, economic, urban and regional order. ${ }^{39}$ The attempt to develop a set of indicators to the conservation state of heritage assets is quite recent, dating from 1999, by the Instituto Andaluz del Patrimonio Histórico (Andalusian Institute of Historical Heritage). However, the proposal has not evolved into an operational phase. In the meetings about this topic, held by UNESCO and the International Centre for the Study of the Preservation and Restoration of Cultural Property (ICCROM), in 2000, 2006, 2007, and 2015, the construction of conservation indicators was encouraged as well as their use as tools to maintain the meaning and values, integrity and authenticity, to identify threats and evaluate public management and use, as well as to allow for the comparison and assessment of sites' changes.

\section{The Barreiro Railway Complex}

The Barreiro Railway Complex is the case study that will be used to test the indicators being developed in my research. There are several reasons for this choice. The first one is the undergoing process of classification for this complex with the aim to be considered as part of the Portuguese national heritage; the second is that this complex has several qualities that can make it a legacy for future generations. Regardless the result of the formal evaluation, it is undoubtedly a cultural asset that embodies Portuguese memory and culture.

A major challenge to the research is the diversity of this complex. It consists of the buildings of the Railway Workshop (Primitive Station), the New Main Station, the Roundabout of the Locomotive Machines, the Railway District, six locomotives and three carriages. Grouped by types, there are buildings (station and workshops), engineering works (roundabout) and rolling stock (locomotives and carriages).

Barreiro was the main station on the south bank of the Tagus River. Close to Lisbon, it was the hot spot when distributing the movement towards the south, to the Algarve. According to Rui Alves ${ }^{40}$ the strategic situation and the presence of various infrastructures made it possible to transform the Barreiro area from a fishing village into one of the largest and main industrial centers in the country.

The early Barreiro Railway Station was built in 1859, with the purpose of working as the Main Railway Station of the South Line. The building was converted into General Workshops in 1884, when the Barreiro-Mar Station (New Main Station) was inaugurated, designed by

${ }^{39}$ Michael Carley, Social Measurement and Social Indicators: Issues of Policy and Theory (London: George Allen \& Unwin, 1985); Cecilia Wong, Indicators for urban and regional planning: The interplay of policy and methods (London: Routledge. 2006).

40 Rui Manuel Vaz Alves, "Arquitetura, Cidade e Caminho de Ferro: As transformaçóes urbanas planeadas sob a influência do caminho de ferro," vol. I (PhD diss., Faculdade de Ciências e Tecnologia da Universidade de Coimbra, 2015), 278. 
engineer Miguel Paes. The new station is considered one of the finest examples of Portuguese engineering due to its location on the banks of the Tagus river and because it involved highly complex hydraulic works. In addition, it was the first multimodal station in the country. ${ }^{41}$

\section{Theoretical and Methodological Framework}

The theoretical and methodological framework used to approach the Barreiro's case study was developed by Lira, ${ }^{42}$ who was a pioneer in this field of inquiry, introducing the relationship between theory and practice.

Two premises are used to guide the operationalization of the concepts of conservation of cultural heritage. The first one is that cultural significance, integrity and authenticity are related to the assessment of heritage attributes, which are the characteristics that most strongly characterize and are more valued in the objects. The second is that the construction of the significance and the assessment of integrity and authenticity must be carried out in its sociocultural context, through an inter-subjective validation process.

In the first premise, heritage attributes ${ }^{43}$ are the main characteristics (material or nonmaterial) of the object; they express its cultural values and need to be kept over time. Lira ${ }^{44}$ proposes that the identification of attributes should be based on five aspects: 1. Context of implantation (urban/rural): related to the implantation of the building, the relationship between of the property and its surroundings, as well as the landscape in which it is inserted; 2. Constructive type: attributes related to the presence of architectural characteristics related to the template, decorative elements, plant solutions, among others; 3. Construction techniques and materials: attributes related to materials and signs of construction technology in the building typology; 4. Patina: attributes that characterize the formation of patina, understood as the effect of the passage of time on the visible surfaces of goods, which must be preserved for historical, aesthetic and technical reasons; 5 . Uses and social practices: attributes of a nonmaterial nature, involved in the dynamics of the use of goods by individuals, that is, processes that foster the building or the site.

Bearing in mind the railway typology, which has both an urban and a local dimension, it may be necessary to use an additional aspect to identify attributes closer to the railways' reality. This is a topic still under consideration in my research.

\footnotetext{
41 "Complexo Ferroviário do Barreiro," Diretoria Geral do Património Cultural, accessed March 30, 2020, http://www.patrimoniocultural.gov.pt/pt/patrimonio/patrimonio-imovel/pesquisa-dopatrimonio/classificado-ou-em-vias-de-classificacao/geral/view/22985201.

${ }^{42}$ Lira, "Da natureza complexa dos bens culturais," 21-23.

${ }^{43}$ Zancheti and Hidaka, Indicadores de Conservação, 37.

${ }^{44}$ Lira, Patrimônio cultural e autenticidade, 220.
} 
The assumption that a collective or intersubjective agreement - i.e. convergence of opinions is needed to legitimize these concepts entails the need to generate consensus, which, in turn, requires a careful approach from experts, stakeholders and the community in which the cultural good is inserted.

To reach this consensus I will use the Delphi method, which is particularly suitable in cases of absence of consolidated scientific knowledge, ${ }^{45}$ such as cultural significance, authenticity and integrity. The Delphi method begins with the filling of anonymous and repeated questionnaires until a common view is reached. Once the consensus is reached for the first indicator, the questionnaire is applied to other social groups directly involved with the object, in order to reach social validation and to enrich the basis of the research with balanced top-down and bottom-up approaches.

It is necessary to understand that cultural significance, integrity and authenticity are dynamic. Objects undergo natural and human actions. Thus, it is necessary to take into account the relationship between object and society because the meaning of cultural goods today may not be the same in a few years from now.

Significance is equivalent to the set of values attributed to the object. The level of significance directly influences how the conservation action will be conducted. Authenticity, in turn, concerns the degree of genuineness of its attributes both in the objective dimension, which is related to the physical-material characteristics of cultural goods, and as the constructive dimension, which refers to the processes or rites of making and remaking cultural goods and the expressive dimension, which is related to the way people experience and relate to these goods and the cultural meanings that emerge from this relationship, relating to the good's ability to express its cultural significance in a true way. ${ }^{46}$ Integrity, on the other hand, is related to the ability of the good's attributes to transmit its significance. All these concepts must be taken into account, as well as the possible transformations, permanent maintenance over time of the physical elements and the necessary dynamics to tell the good's story. ${ }^{47}$

45 James T. C. Wright and Renata Alves Giovinazzo, "DELPHI - uma ferramenta de apoio ao planejamento prospectivo," Caderno de Pesquisas em Administração 1, no. 12 (2000): 54-65, on 54.

${ }^{46}$ Lira, Patrimônio cultural e autenticidade, 178 (objective dimension), 169-170 (constructive dimension), 193 (expressive dimension).

${ }^{47}$ Jukka Jokilehto tries to show that integrity is beyond matter by proposing its interpretation based on three dimensions. Social Functional Integrity: referring to the identification of social functions and development processes peculiar to the place where the heritage is inserted; Structural Integrity: Related to physical-material identification that documents socio-functional characteristics of the heritage; and Visual Integrity: Required to identify the aesthetic aspects of the place. See Jokilehto, "Considerations." 


\section{Final Remarks}

This is a work in progress and the theoretical-methodological approach described above, to frame the fieldwork in the Barreiro railway complex, corresponds to a dense and fundamental part of the thesis that has been developed. At this moment and following the methodological guidelines to assess the parameters of the concepts of conservation, cultural significance, authenticity and integrity of the railway heritage, I'm close to achieve the application of the Delphi method to experts and then move to the local community for validation.

After the fieldwork, with the data collected, I expect to be able to identify possible needs for adjustments in the theoretical framework vis a vis the railways' reality, thus contributing to its efficiency in assessing the conservation of cultural goods and specially the railway heritage.

It is expected that at the end of this investigation, this work can contribute to science of conservation by giving a new approach to concepts that facilitate the understanding by academics and technical professionals of heritage, also presenting the indicators as tools that can be used by institutions working on heritage conservation, to identify and evaluate the wide railway universe, besides other goods of industrial and technological heritage.

\section{Competing Interests}

The author has declared no competing interests exist.

\section{Funding}

This research is being supported by a CIUHCT scholarship (UID/HIS/00286/2020). 